\title{
Regulator of G-Protein Signaling 22
}

National Cancer Institute

\section{Source}

National Cancer Institute. Regulator of G-Protein Signaling 22. NCI Thesaurus. Code C114444.

Regulator of G-protein signaling 22 (1264 aa, 147 kDa) is encoded by the human RGS22 gene. This protein plays a role in the modulation of both GT Pase activity and signal transduction. 